\title{
8. Walne Zebranie Stowarzyszenia Biblistów Polskich i 49. Sympozjum Biblistów Polskich (Katowice, 20-22 września 2011)
}

Katowice były miejscem dorocznego spotkania biblistów polskich, którzy obradowali tam już w 1986 roku na 23. sympozjum. Gospodarzami było Wyższe Śląskie Seminarium Duchowne oraz Wydział Teologiczny Uniwersytetu Śląskiego w Katowicach. Udział w tegorocznym spotkaniu wzięło około 170 osób.

We wtorek 20 września wieczorem odbyło się 8 . Walne Z ebranie Stowarzyszenia Biblistów Polskich. Otworzył je modlitwą i prowadził ks. prof. Waldemar Chrostowski, przewodniczący stowarzyszenia. W swoim wystąpieniu wspomniał zmarłego 30 kwietnia 2011 ks. prof. dr. hab. Ryszarda Rubinkiewicza SDB, zwyczajnego i honorowego członka stowarzyszenia, wykładowcę Katolickiego Uniwersytetu Lubelskiego, wieloletniego prezesa Sekcji Biblistów Polskich Konferencji Episkopatu Polski (1993-2003), a następnie przedstawił sytuację stowarzyszenia. Liczy ono obecnie 278 członków zwyczajnych, w tym 80 samodzielnych pracowników naukowych, posiada stronę internetową w języku polskim i angielskim www.sbp.net.pl i przy tym dużym potencjale zakorzenia się coraz bardziej w środowisku naukowym i kościelnym, współpracując z różnymi uczelniami i instytucjami, najściślej z Dziełem Biblijnym im. Jana Pawła II. Dziękując wszystkim członkom za współpracę w minionym roku, przewodniczący zwrócił uwagę na kwestie wymagające ciągłego zaangażowania wszystkich: dalszy wzrost liczby członków i integrację wewnętrzną, podnoszenie standardów naukowych i dydaktycznych, wzajemną pomoc w awansach naukowych, troskę o dobre publikacje, wykłady i programy, aktualizację danych z ewentualnym pominięciem informacji wrażliwych. Zachęcił też do zgłaszania kandydatur do nagrody stowarzyszenia i członkostwa honorowego oraz do opracowań nt. historii biblistyki polskiej w zakresie całego kraju i w poszczególnych ośrodkach, także na tle biblistyki zagranicznej, która to tematyka powinna się znaleźć w centrum jubileuszowego 50. sympozjum w roku następnym. $\mathrm{Na}$ koniec poprosił o nadsyłanie artykułów do ksiąg jubileuszowych dla ks. prof. dr. hab. Jana Łacha i dla ks. dr. hab. Józefa Kozyry z okazji ich 85. i 65. urodzin.

Następnie skarbnik stowarzyszenia o. dr hab. Ryszard Sikora OFM złożył sprawozdanie finansowe przyjęte jednogłośnie w głosowaniu. W kolejnym głosowaniu przyjęto 
wniosek zarządu stowarzyszenia o nadanie członkostwa honorowego ks. prof. dr. hab. Stanisławowi Bieleckiemu dotkniętemu utratą wzroku oraz dwa otwarte listy protestacyjne zaprezentowane przez ks. prof. Waldemara Chrostowskiego: do prezesa zarządu Telewizji Polskiej SA Jerzego Brauna w związku z zatrudnieniem w programie The Voice of Poland satanisty znanego m.in. z publicznego podarcia Biblii Adama Nergala, ps. Holocausto vel Nergal, i do rektor Uniwersytetu Warszawskiego prof. dr hab. Katarzyny Chałasińskiej-Macukow w sprawie wypowiedzi dr hab. Magdaleny Środy, że ona również chętnie podarłaby Biblię. Dzieło Biblijne wystosowało odrębny protest w sprawie Nergala.

W wolnych wnioskach ks. dr hab. Piotr Ostański poinformował o elektronicznej wersji Bibliografii biblistyki polskiej za lata 1945-2010/2011, zawierającej około 50 tys. opisów zebranych w opublikowanych 4 tomach i nadesłanych w ostatnim czasie. Zebrani podziękowali mu za 14-letnią pracę długą owacją i chętnie skorzystali z możliwości nabycia CD. Z kolei ks. dr hab. Krzysztof Bardski zachęcił do starania się o granty badawcze oceniane przez grono ekspertów, w którym zasiada obok innych trzech przedstawicieli dyscyplin teologicznych. Następnie ks. prof. dr hab. Henryk Witczyk, przewodniczący Dzieła Biblijnego i dyrektor Instytutu Nauk Biblijnych Katolickiego Uniwersytetu Lubelskiego Jana Pawła II, poinformował o Pierwszym Kongresie Biblijnym pod hasłem Biblia kodem kulturowym Europy zorganizowanym przez dwie wspomniane instytucje, który odbędzie się w dniach 28-30 października 2011 w Warszawie i Toruniu z udziałem m.in. kard. Gianfranca Ravasiego. Na koniec ks. dr hab. Józef Kozyra poinformował, że 6 września zmarł o. dr Damian Szojda OFM, biblista, wykładowca Pisma Świętego w Wyższym Seminarium Duchownym w Panewnikach, tłumacz 1-2 Tes w Biblii Poznańskiej z 1975 roku, dobroczyńca naszego stowarzyszenia. Zebranie zakończono Apelemjasnogórskim.

Środę 21 września, święto apostoła i ewangelisty Mateusza, patrona biblistów, rozpoczęła msza święta koncelebrowana pod przewodnictwem abpa Damiana Zimonia, metropolity katowickiego. W homilii ukazał on postawę Jezusa, który szedł także do grzeszników i celników. Podkreślił ważną rolę, jaką pełni istniejący Wydział Teologiczny w zindustrializowanym i zurbanizowanym regionie Górnego Śląska oraz bogate tradycje apostolatu biblijnego w archidiecezji, którego pionierem był założyciel Ruchu Świało-Życie ks. Franciszek Blachnicki, a w który dzisiaj włączają się aktywnie media: „Gość Niedzielny”, „Mały Gość Niedzielny” i Radio eM.

49. Sy m pozjum Biblistów Polskich otworzyłks. prof. drhab. Waldemar Chrostowski, po czym ks. dr hab. Andrzej Żądło, dziekan Wydziału Teologicznego Uniwersytetu Śląskiego, przywitał wszystkich uczestników i życzył owocnych obrad. I sesji przewodniczył ks. dr Henryk Drawnel SDB z ks. dr. hab. Grzegorzem Szamockim $\mathrm{i}$ ks. dr. Wojciechem Michniewiczem. Na początku referat $W$ poszukiwaniu śladów asyryjskiej diaspory Izraelitów w Księdze Ezechiela wygłosił ks. dr hab. Wojciech Pikor, opowiadając się raczej przeciw możliwości przetrwania zorganizowanej społeczności wysiedlonych do Asyrii w VIII-VII wieku Izraelitów aż do nowego wysiedlenia babilońskiego w VI wieku przed Chrystusem (za istnieniem takiej diaspory opowiada się ks. prof. dr hab. Waldemar Chrostowski). Po nim dr Wojciech Kosek w komunikacie Logika „błędnego koła” i jej przezwyciężanie w egzegezie naukowej XX wieku zwrócił uwagę na potrzebę wychodzenia w egzegezie od tekstu, a nie od uprzednich hipotetycznych założeń. 
Po dyskusji i przerwie na kawę miała miejsce II sesja pod przewodnictwem s. dr Jolanty Judyty Pudełko PDDM z dr Iwoną Zielonką i ks. dr. hab. Januszem Kręcidłą MS. W referacie Bić sięczy się nie bić? Biblijne reakcje na przemoc obcych imperiów prof. dr hab. Michał Wojciechowski ukazał różne zachowania Izraelitów wobec najeźdźców: od walki zbrojnej poprzez opór bierny aż do pewnej współpracy, której granicą była wierność jedynemu Bogu. Z komunikatu ks. dr. Macieja Basiuka Pięcioksiag w Qumran. Implikacje teologiczne można było się dowiedzieć, że spośród ksiąg biblijnych Pięcioksiąg jest najlepiej reprezentowany w Qumran, choć Księga Rodzaju zawiera luki i ma różne wersje, co każe postawić pytanie, czy pierwsza część Biblii hebrajskiej miała już definitywną postać na przełomie er.

Po dyskusji nastąpiła uroczystość wręczenia ksiąg pamiątkowych bpowi drowi hab. Zbigniewowi Kiernikowskiemu Nie wstydzę się Ewangelii i ks. prof. drowi hab. Waldemarowi Chrostowskiemu Więcej szczęścia jest $w$ dawaniu aniżeli w braniu, t. I-III. Następnie ks. dr hab. Stanisław Hałas SCJ wygłosił laudację dla ks. prof. dr. hab. Stanisława Bieleckiego, który dzień wcześniej otrzymał członkostwo honorowe stowarzyszenia. Przypomniał jego drogę życiową, kapłańską i zwłaszcza naukową: studia w Lublinie i w Rzymie, pobyt w Ziemi Świętej, wykłady na Katolickim Uniwersytecie Lubelskim Jana Pawła II i za granicą wschodnią, publikacje egzegetyczne, pedagogiczne i homiletyczne, tłumaczenia na język białoruski i słowacki, funkcja dyrektora Instytutu Pastoralno-Katechetycznego Wydziału Teologicznego Katolickiego Uniwersytetu Lubelskiego, założenie czasopisma „Keryks. Międzynarodowy Przegląd Katechetyczno-Pedagogicznoreligijny". Liczne wydawnictwa i autorzy przedstawili komunikaty nt. najnowszych publikacji, które można było także nabyć. Tradycyjnie zrobiono też wspólne zdjęcie.

Po obiedzie chętni udali się na teren Kopalni Węgla Kamiennego Wujek, gdzie 16 grudnia 1981 roku zginęło 9 górników w czasie pacyfikacji kopalni przez funkcjonariuszy MO i ZOMO oraz żołnierzy. Zapalono znicz przed krzyżem i odmówiono modlitwę za poległych i ich rodziny. Trzech górników biorących udział w tamtych wydarzeniach podzieliło się swymi wspomnieniami i aktualnymi refleksjami, natomiast w Muzeum Izbie Pamięci można było zobaczyć makietę pacyfikacji, autentyczne eksponaty (np. użyte pociski, przestrzelony hełm) oraz film TVP 3 nt. procesu zabójców i obecnej sytuacji rodzin ofiar. Inni bibliści mogli w tym czasie nawiedzić katedrę katowicką.

Po kawie rozpoczęła się III sesja, której przewodniczył ks. dr hab. Józef Kozyra z ks. dr. hab. Krystianem Ziają i ks. dr. hab. Zdzisławem Żywicą. Złożyły się na nią dwa referaty. Ks. dr Wojciech Węgrzyniak mówił o Wyzwaniach wspótczesnej biblistykina przykładzie Ps 14. Postulował, aby uwzględniać różne warianty tekstu, kierować się bardziej argumentami niż autorytetami, nie powielać znanych tez, ale dzielić się odkrywczymi wynikami swoich dociekań, interpretować Biblię w kluczu chrystologicznym, odpowiadając na współczesne problemy. Z kolei dr hab. Adam Linsenbarth przedstawił Rozwój światowej kartografii biblijnej w okresie od XV do XIX wieku, ilustrując swój wykład zdjęciami licznych map pochodzących z różnych krajów Europy i Ameryki Północnej. Po dyskusji i kolacji miało miejsce spotkanie towarzyskie, które jest zawsze dobrą okazją do lepszego poznania się i wymiany poglądów.

Czwartek 22 września rozpoczął się również od mszy świętej koncelebrowanej, której przewodniczyłbp Zbigniew Kiernikowski. Nawiązując do czytań mszalnych o od- 
budowie świątyni (Ag 1) i niepokoju Heroda (Łk 9), apelował w homilii, aby nie myśleć tylko o swej stabilizacji, ale budować wspólnotę Kościoła i aby otwierać się w pełni na Chrystusa przemawiającego w Piśmie Świętym i iść za Nim bez wahań.

W czasie IV sesji prowadzonej przez ks. dra hab. Stefana Szymika MSF z o. drem Bernardem Arndtem OFM i ks. drem Stanisławem Wronką najpierw referat Geneza Prawa Mojżeszowego według teologii Pawłowej wygłosił ks. prof. dr hab. Waldemar Rakocy CM. Argumentował, że Prawo ma dla Pawła charakter służebny wobec obietnicy danej Abrahamowi i urzeczywistnionej w Chrystusie, bo zostało dane i zarządzane przez aniołów $(\mathrm{Ga} 3,19)$. Natomiast dr Beata Urbanek w komunikacie Idea przymierza w mowie Jezusa o pasterzu, bramie i owcach (J 10,1-18. 26-29) wypunktowała elementy przymierza w tej perykopie, pokazując, że idea przymierza nie jest obca Ewangelii Janowej, mimo że brak w niej samego terminu „przymierze”.

Po dyskusji i kawie rozpoczęła się ostatnia V sesja pod przewodnictwem ks. prof. dra hab. Romana Bartnickiego z ks. drem hab. Dariuszem Koteckim i o. dr. Piotrem Gryźcem OFMConv. Ks. dr hab. Krzysztof Bardski w referacie Od obrazu biblijnego do kontemplacji tajemnic wiary ukazał alegoryczno-symboliczną interpretację Biblii rozpowszechnioną w starożytności i średniowieczu i mogącą także dzisiaj pomagać dotrzeć do rzeczywistości wiary, do Chrystusa, wychodząc od sensu dosłownego i uwzględniając jedność Biblii, analogię wiary i autorytet tradycji. W miejsce referatu Współczesne kierunki w badaniach nad Listem św. Jakuba nieobecnej dr Doroty Muszytowskiej o. Bernard Arndt OFM przedstawił komunikat archeologiczny nt. ciekawych znalezisk w Magdali, które potwierdzają opisy Józefa Flawiusza dotyczące tej miejscowości, oraz na tellu (wzgórzu) położonym na zachód od Jeziora Genezaret.

Po końcowej dyskusji ks. prof. dr hab. Waldemar Chrostowski podsumował całe spotkanie, podziękował gospodarzom i wszystkim uczestnikom oraz zapowiedział, że 9. Walne Zebranie Stowarzyszenia Biblistów Polskich i 50. Sympozjum Biblistów Polskich odbędą się w Warszawie w dniach 18-20 września 2012. Wspomniał też, że istnieje możliwość wspólnego wyjazdu do Wilna. Zakończył modlitwą Anioł Pański w intencjach Benedykta XVI przebywającego w Niemczech z wizytą duszpasterską. 